Article

\title{
Application of Composite NanoMaterial to Determine Phenols in Wastewater by Solid Phase Micro Membrane Tip Extraction and Capillary Electrophoresis
}

\author{
Nora Hamad Al-Shaalan ${ }^{1, *}$, Imran Ali ${ }^{2,3, *} \mathbb{C}^{\circ}$, Zeid A. ALOthman ${ }^{4}(\mathbb{B}$, \\ Lamya Hamad Al-Wahaibi ${ }^{1}$ and Hadeel Alabdulmonem ${ }^{1}$ \\ 1 Department of Chemistry, P. O. Box 84428, College of Science, Princess Nourah bint Abdulrahman University, \\ Riyadh 11671, Saudi Arabia; Lhalwahaib@pnu.edu.sa (L.H.A.-W.); haalabdulmenem@pnu.edu.sa (H.A.) \\ 2 Department of Chemistry, College of Sciences, Taibah University, Al-Medina Al-Munawara 41477, \\ Saudi Arabia \\ 3 Department of Chemistry, Jamia Millia Islamia, (Central University) New Delhi 11025, India \\ 4 Department of Chemistry, P. O. Box 2455, College of Science, King Saud University, Riyadh 11451, \\ Saudi Arabia; zaothman@ksu.edu.sa \\ * Correspondence: nhalshaalan@pnu.edu.sa (N.H.A.-S.); drimran.chiral@gmail.com (I.A.)
}

Academic Editors: Clinio Locatelli; Marcello Locatelli and Dora Melucci

Received: 29 August 2019; Accepted: 20 September 2019; Published: 23 September 2019

check for updates

\begin{abstract}
Composite nanoparticles were used in solid phase micro membrane tip extraction and capillary electrophoresis to determine phenol and $p$-amino-phenol in wastewater. The optimized conditions were $100 \mathrm{~g} / \mathrm{L}$ concentration, $40 \mathrm{~min}$ contact time, $11 \mathrm{pH}, 5 \mathrm{mg} / \mathrm{mL}$ nanoparticles amounts, 60 min desorption time, 9 desorption $\mathrm{pH}$ and $298 \mathrm{~K}$ temperature. Capillary electrophoresis conditions were phosphate buffer $(15 \mathrm{mM}, \mathrm{pH} 7.0)$ background electrolyte, $18 \mathrm{kV}$ applied voltage, $214 \mathrm{~nm} \mathrm{UV}$ detection, $30 \mathrm{~s}$ sample loading at $23 \pm 1{ }^{\circ} \mathrm{C}$. The maximum percent uptakes of $p$-amino-phenol and phenol were 80.0 and $85.0 \%$. High ratio recoveries of $p$-amino-phenol and phenol from nanomaterial were 99.0 and 98 . Consequently, the actual extractions of $p$-amino-phenol and phenol from wastewater were 79.2 and 83.30 percent. The migration times of phenol and $p$-amino-phenol and were 9.0 and $12.0 \mathrm{~min}$. The detection limits of phenol and $p$-amino-phenols were 0.1 and $0.2 \mu \mathrm{g} / \mathrm{L}$ after extraction and CE. Therefore, this combination of solid phase micro membrane tip extraction and capillary electrophoresis may be considered as the ideal one for monitoring of toxic phenol and $p$-amino-phenol in water sample.
\end{abstract}

Keywords: phenol; 3-aminophenol; wastewater; SPMMTE; capillary electrophoresis

\section{Introduction}

The analysis of any sample of natural origin comprises two parts, that is, sample preparation and separation and identification. The first part of the experiment becomes important in case of the samples of biological and environmental origins. This is due to the fact that, sometimes, more than hundreds of impurities are present in the samples of the natural origin [1,2]. Hence, sample preparation is one of the crucial issues in the separation science. Many sample preparation methods are reported in the literature and these comprise liquid-liquid extraction, solid phase extraction, solid phase micro-extraction (SPME), supercritical fluid extraction, ultrasonic extraction, pressurized liquid extraction, empty fiber liquid phase micro-extraction, micro-wave assisted extraction, dispersive liquid-liquid micro-extraction, molecularly imprinted solid phase extraction, pressurized hot water extraction and solid phase micro membrane tip extraction (SPMMTE). Among these, the later method is supposed as the best one 
due to the involvement of low amount of adsorption media, fast extraction, capable to work at low concentration and low sample volume. This method is used for the extraction of some species from samples of biological and environmental importance [3,4]. Phenols are very notorious water pollutants and need to be monitored even at low concentration for which SPMMTE may be a choice of the sample preparation. Phenols have acute toxicities [5-15] along with tumorigenesis [16-20]. The collective causes of phenols pollution are industries related to dyes, textiles, pesticides, paper, pharmaceutical, tanning, plastic, gasoline, rubber and so forth [21,22]. Some systems are described for analyses but many of them consume high volume of toxic solvent and sorbent materials [23]. Besides, some techniques are not skilled for phenolic extraction at micro level concentration in water [24]. Taking these assessments into deliberation, composite iron nanomaterial is manufactured and used in SPMMTE for sample preparation of phenols containing water. Analysis of phenol was carried out by capillary electrophoresis [25].

\section{Results and Discussion}

The characterization of the synthesized composite iron nanoparticles, determination of phenols by capillary electrophoresis and optimization of the extraction of phenols in SPMMTE are discussed.

\subsection{Characterization of the Synthesized Composite Iron NanoParticles}

The prepared composite iron nanoparticles were categorized by XRD, TEM and SEM methods. The detail of the description is described elsewhere [26-29]. XRD peaks were observed at $2 \theta$ of 18.6 and 44.8; indicating presence of $\mathrm{FeOOH}$ and $\mathrm{Fe}^{0}$ (zero valent iron). Further XRD peak show amorphous nature of nanocomposite. TEM results reflect the roughness of the surface and SEM results indicates 10-30 nm particle size.

The supra molecular structure of the composite iron nanoparticle is revealed in Figure 1.

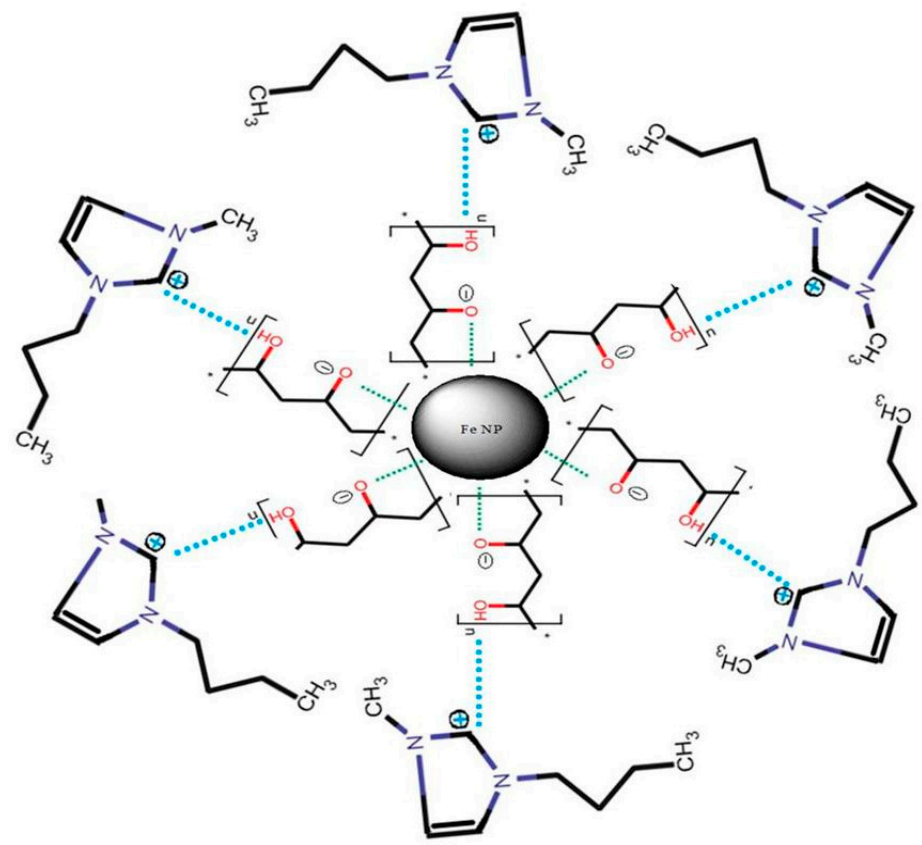

Figure 1. The supra molecular structure of the composite iron nanoparticle.

\subsection{Determination of Phenols by Capillary Electrophoresis}

Analysis of phenols in water was done by noting their migration times. The documentation of the separated phenols was carried out using standards of the phenols. The values of the migration times of phenol and 3-aminophenol in CE were 9.0 and $12.0 \mathrm{~min}$. The capillary electrophoresis optimization was carried out by achieving the variation in the configuration of background electrolyte, $\mathrm{pH}$ of 
the background electrolyte, amount of sample loaded and capillary length and voltage. The best conditions were used in this paper. The validation data was also collected for this set of experiment and found \pm 0.70 to \pm 0.8 as standard deviation, 0.9997 to 0.9998 correlation coefficients and 98.8 to 99.0 confidence level.

\subsection{Validation of Capillary Electrophoresis}

The capillary electrophoretic method was validated as per standard procedure [30,31]. The valuables studied were linearity, specificity, limit of detection (LOD), limit of quantification (LOQ), accuracy, precision and ruggedness. The magnitudes of these variables are given in Table 1 . It is lucid for the table that the developed method is accurate, specific, précised and rugged.

Table 1. Validation parameters of capillary electrophoresis.

\begin{tabular}{ccccc}
\hline S1. No. & Validated Parameters & \% RSD & Correlation Coefficients & Confidence Levels \\
\hline 1. & Linearity & $0.55-1.20$ & $0.9996-0.9997$ & $97.0-96.2$ \\
2. & LOD & $0.85-1.30$ & $0.9995-0.9996$ & $95.5-96.1$ \\
3. & LOQ & $0.83-0.102$ & $0.9995-0.9996$ & $96.6-96.0$ \\
4. & Specificity & $0.73-0.93$ & $0.9995-0.9996$ & $97.0-96.1$ \\
5. & Accuracy & $0.69-0.87$ & $0.9996-0.9998$ & $96.2-96.2$ \\
5. & Precision & $0.58-0.71$ & $0.9996-0.9998$ & $96.2-97.0$ \\
6. & Ruggedness & $0.89-1.40$ & $0.9995-0.9996$ & $96.7-96.6$ \\
\hline
\end{tabular}

\subsection{Extraction of Phenols by SPMMTE}

To attain the maximal extraction of phenols with SPMMTE, numerous parameters were diverse and improved. The diverse settings were concentrations of phenols, $\mathrm{pH}$, contact time, nanoparticles amount bounded in a cone of membrane and the temperature.

\subsubsection{Concentrations of Phenols}

Primarily, with an augment in concentration from 25.0 to $100.0 \mu \mathrm{g} \mathrm{L}^{-1}$ the quantity of sorption in aminophenol and phenol progressively augmented from 5.0 to $16.0 \mu \mathrm{g} / \mathrm{mg}$ that is, $100-80 \%$. Subsequently, more increase in concentration up to $150.0 \mu \mathrm{g} \mathrm{L} \mathrm{L}^{-1}$, the sorption of both remained persistent. Extra limitations; interaction time $40 \mathrm{~min}, \mathrm{pH} 11.0$, dose $5.0 \mathrm{mg} / 10 \mathrm{~mL}$ and temperature $298 \mathrm{~K}$ were attuned. The upshot of this process is given in Figure 2, that evidently displays the sorption of $5.0,10.0,13.50,16.0,16.0$ and $16.0 \mu \mathrm{g} / \mathrm{mg}$ at 25.0, 50.0, 75.0, 100.0, 125.0 and $150.0 \mu \mathrm{g} / \mathrm{L}$ concentrations for amino-phenol. Whereas in the event of phenol sorption of 5.0,10.0, 14.0, 17.0, 17.0 and $17.0 \mu \mathrm{g} / \mathrm{mg}$ at $25.0,50.0,75.0,100.0,125.0$ and $150.0 \mu \mathrm{g} / \mathrm{L}$ concentrations were gotten. It obviously confirms that an extra increase in concentration from $100.0-150.0 \mu \mathrm{g} / \mathrm{L}$ could not boost the sorption. So, a typical of concentration of $100 \mu \mathrm{g} \mathrm{L}{ }^{-1}$ was preferred for the remaining experiments.

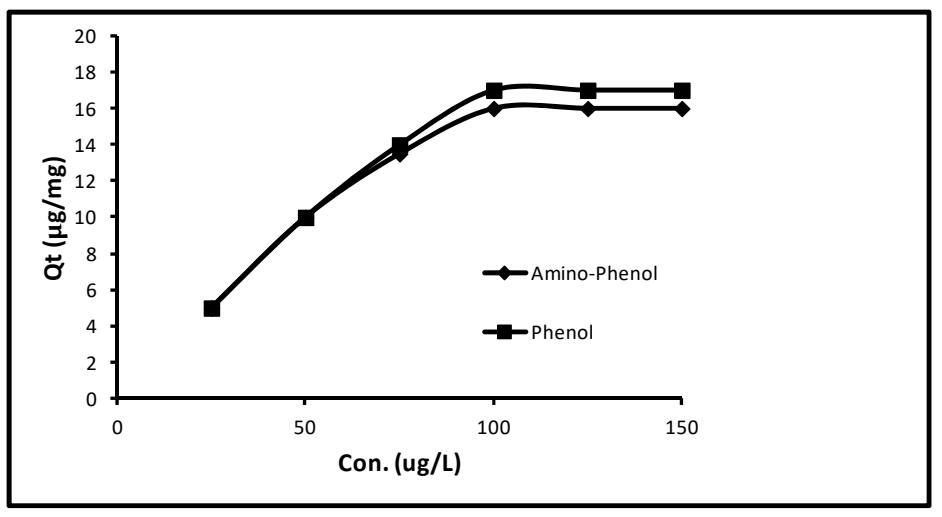

Figure 2. Effect of initial concentrations of phenols. 


\subsubsection{Extraction Time}

With an augment of interaction time from 5.0 to $60.0 \mathrm{~min}$, the sorption frequently gets augmented for aminophenol and phenol till $40.0 \mathrm{~min}$. Then the sorption remained static for both the molecules. Limitations such as concentration, $\mathrm{pH}$, dose and temperature were $100 \mu \mathrm{g} \mathrm{L} \mathrm{L}^{-1}, 11.0,5.0 \mathrm{mg} / 10 \mathrm{~mL}$ and $298 \mathrm{~K}$ were utilized, correspondingly. The contact time effect on sorption is revealed in Figure 3. It may be observed from the figure the sorption in aminophenol and phenol were 4.0, 6.0, 10.0, 14.0 and $16.0 \mu \mathrm{g} / \mathrm{mg}$ that is, 20.0, 30.0, 50.0, 70.0 and $80.0 \%$ at 5.0, 10.0, 20.0, 30.0 and $40.0 \mathrm{~min}$ and 4.0, 6, $10.50,14.50$ and $17 \mu \mathrm{g} / \mathrm{mg}$ that is, 20.0, 30.0, 50.0, 72.50 and $85.0 \%$ at 5.0, 10.0, 20.0, 30.0 and $40.0 \mathrm{~min}$, correspondingly. Additionally, with a rise in contact time the sorption remained unaltered for both molecules. So, at $40.0 \mathrm{~min}$ contact time, the rest runs were done.

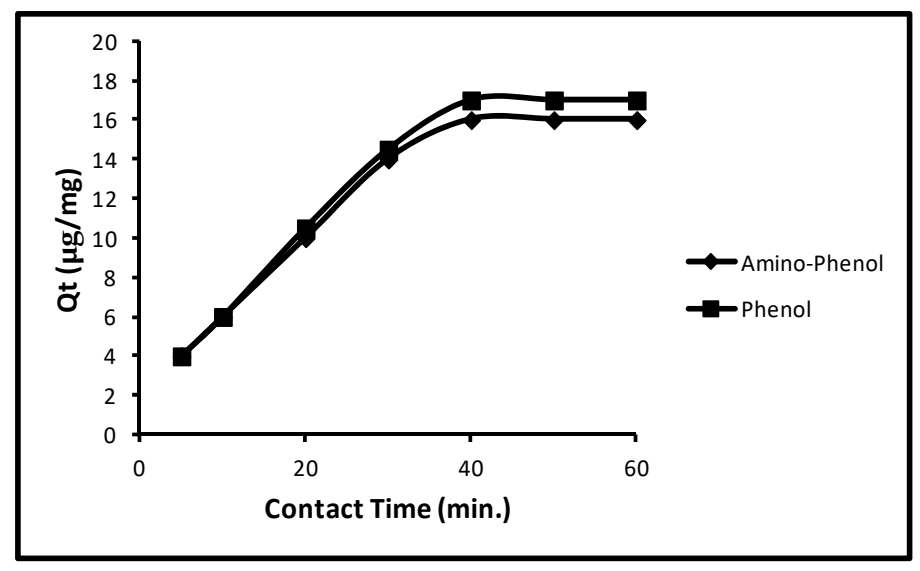

Figure 3. Effect of extraction time of phenols.

\subsection{3. $\mathrm{pH}$ of the Solutions of Phenols}

In the event of $\mathrm{pH}$ effect on the sorption, primarily the sorption of aminophenol and phenol increased from 2.0 to $16.0 \mu \mathrm{g} / \mathrm{mg}$, that is, $10.0-80.0 \%$ at $9.0-10.50 \mathrm{pH}$; followed by the unaffected until 13.0. The extra limitations used were contact time $(40.0 \mathrm{~min})$, concentration $\left(100 \mu \mathrm{g} \mathrm{L}^{-1}\right)$, dose $(5.0 \mathrm{mg} / 10 \mathrm{~mL})$ and temperature $(298 \mathrm{~K})$. The effect of $\mathrm{pH}$ on sorption is revealed in Figure 4 . A review of this figure shows that the quantity of sorption for aminophenol was 2.0, 3.0, 5.0, 16.0 and 16.0 $\mu \mathrm{g} / \mathrm{mg}$, that is, $10.0,15.0,25.0,80.0$ and $80.0 \%$ at $9.0,9.50,10.0,10.50$ and $11.0 \mathrm{pH}$. Whilst for phenol at similar $\mathrm{pH}$ values, the attained sorption percentages were 10.0, 15.0, 25.0, 80.0 and 80.0. Also, for both molecules the further alteration in $\mathrm{pH}$ could not augment the sorption. So, a $\mathrm{pH}$ of 11.0 remained a standard one. This performance of phenol sorption was because of pKa values of phenol and $p$-amino-phenol (9.95 and 10.30). 


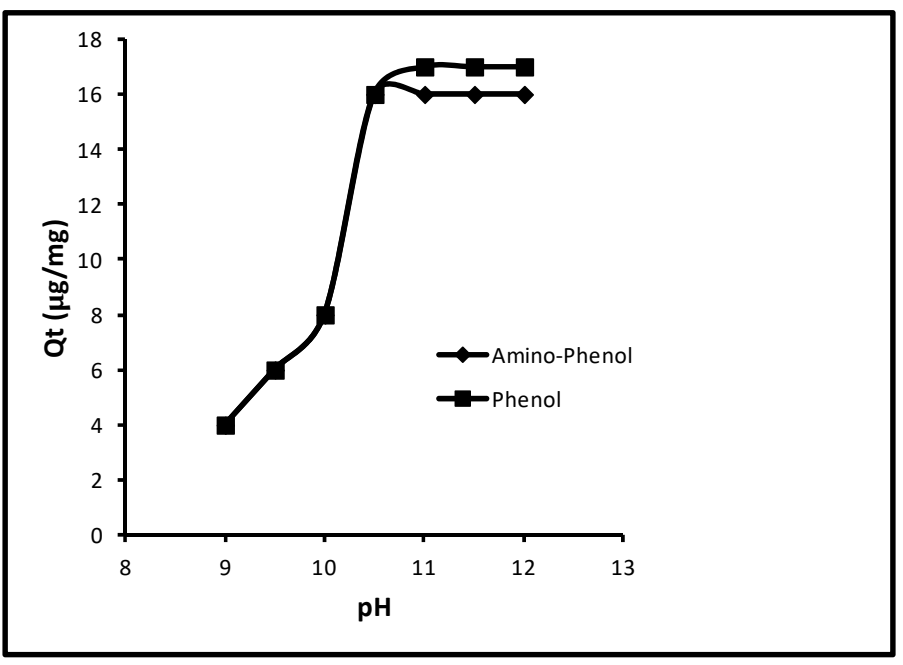

Figure 4. Effect of $\mathrm{pH}$ of the solutions of phenols.

\subsubsection{Amount of Nanosorbent Enclosed in the Membrane Cone}

The effect of the amount of nanosorbent enclosed in the membrane cone was observed while making the other limitations at contact time (40.0 min), $\mathrm{pH}(11.0)$, concentration $(100 \mu \mathrm{g} / \mathrm{L})$ and temperature $(298 \mathrm{~K})$. The amount of the nanosorbent effect enclosed in the membrane cone on the sorption of phenols is revealed in Figure 5 . It was seen that up to $5.0 \mathrm{mg} / 10 \mathrm{~mL}$, the quantity of sorption gradually augmented and then it remained unchanged. At doses of 1.0, 2.0, 3.0, 4.0, 5.0, 6.0 and $7.0 \mathrm{mg} / 10.0 \mathrm{~mL}$ the removal of 3.0, 7.0, 10.0, 13.0, 16.0, 16.30, $16.50 \mu \mathrm{g} / \mathrm{mg}$ with 15.0, 35.0, 50.0, 65.0, 80.0, 81.50 and $81.50 \%$, correspondingly, was noted in case of aminophenol. Whilst a similar quantity of uptake was 3.0, 7.0, 10.50, 13.50, 17.0, 17.50 and $17.60 \mu \mathrm{g} / \mathrm{mg}$ with 15.0, 35.0, 52.50, 67.50, 85.0, 87.0 and $87.0 \%$ for phenol. So, $5.0 \mathrm{mg} / \mathrm{mL}$ was the best quantity of nanosorbent enclosed in the membrane cone.

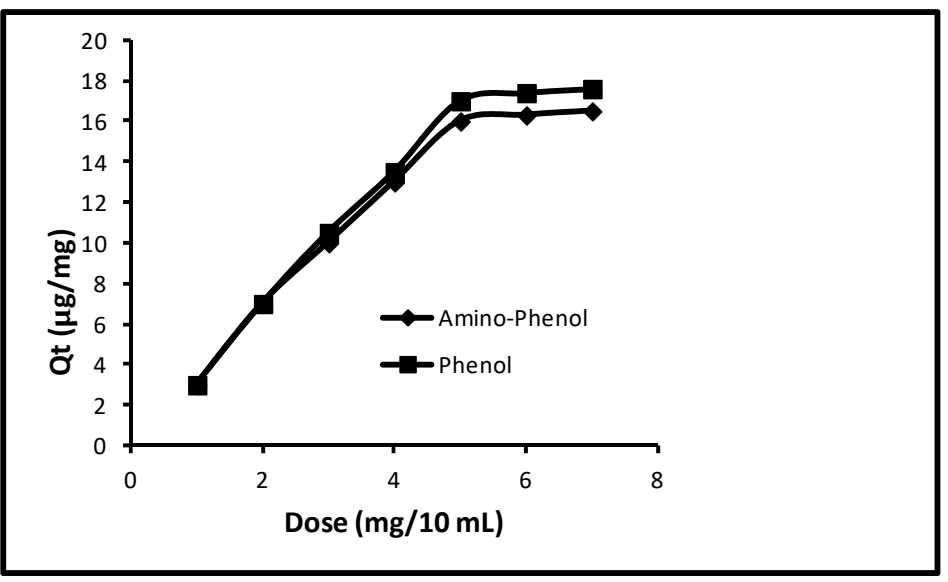

Figure 5. Effect of amount of nanoparticles enclosed in the membrane cone.

\subsubsection{Desorption Time}

While keeping the parameters such as the $40 \mathrm{~min}$ contact time, $100 \mu \mathrm{g} / \mathrm{L}$ concentration, $5.0 \mathrm{mg} / 10 \mathrm{~mL}$ dose and $298 \mathrm{~K}$ temperature, the effect of time on desorption for aminophenol and phenol was experimented and it was found that with an increase in time interval from 5 to $60 \mathrm{~min}$, \% recoveries of both increased constantly (Figure 6) but, on reaching $60 \mathrm{~min}$, \% recoveries remained unaffected that is, constant \% recoveries. From Figure 3, it is clear at 5, 10, 20, 30, 40 and $50 \mathrm{~min}$ that the \% recoveries for aminophenol were 42, 58, 65, 75, 85 and 100 and for phenol 40, 55, 60, 70, 80 and 100, respectively. 
Therefore, it is concluded that, with further increase in time interval after $60 \mathrm{~min}$, the desorption could not be changed.

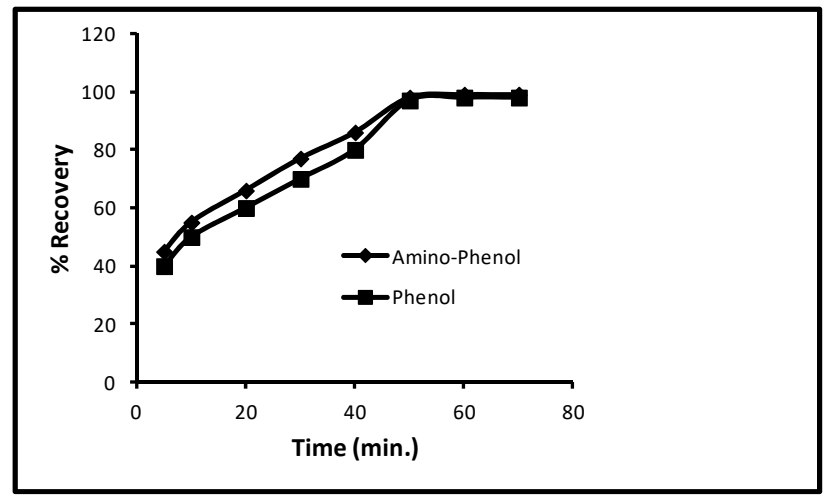

Figure 6. Effect of desorption time for phenols.

\subsubsection{Desorption $\mathrm{pH}$}

Another experiment in which the effect of $\mathrm{pH}$ on the desorption of aminophenol and phenol was tested and other limitations used were a 40 min contact time, $100 \mu \mathrm{g} / \mathrm{L}$ concentration, $5.0 \mathrm{mg} / 10 \mathrm{~mL}$ dose and $298 \mathrm{~K}$ temperature. The readings showed that when $\mathrm{pH}$ was increased from 9 to 12 for aminophenol and phenol the rate of desorption decreased progressively. The effect of $\mathrm{pH}$ on desorption is shown in Figure 7 which depicts, at 9, 9.5, 10, 10.5, 11, 11.5 and $12 \mathrm{pH}$, that the percentage recovery for aminophenol and phenol was 100, 100, 89, 78, 76, 65 and 45 and 100, 100, 90, 77, 75, 60 and 40 respectively. This performance of phenol sorption was because of the pKa values of phenol and p-amino-phenol (9.95 and 10.30).

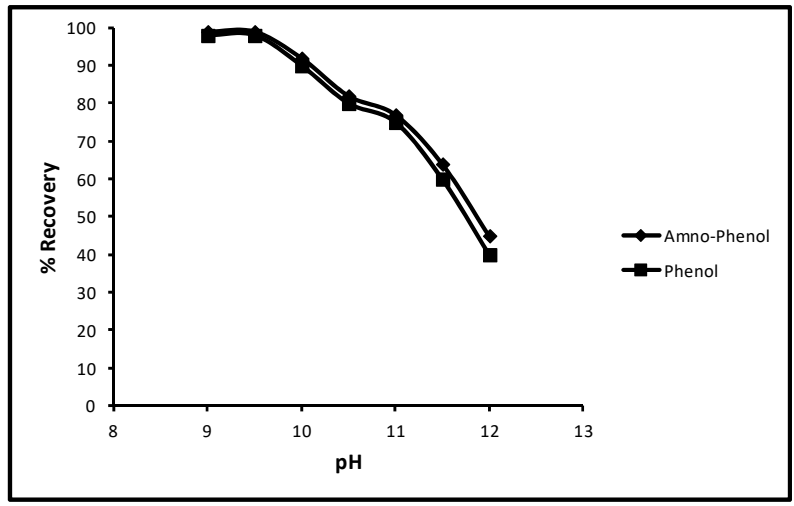

Figure 7. Effect of $\mathrm{pH}$ for desorption of phenols.

\section{Materials and Methods}

\subsection{Chemicals and Reagents}

Phenol and 3-aminophenol (Figure 8) and nitro-phenol (internal standard) were obtained from Aldrich Chemical Co., St. Louis, MO, USA. Sodium phosphate and sodium dihydrogen phosphate were supplied by SRL, Mumbai, India. N-methyl butyl imidazolium bromide, that is, ionic liquid (IL) was obtained from Fluka, Mumbai, India. Ferrous sulphate and poly vinyl alcohol (PVA) were supplied by Qualigens Mumbai, India. Millipore water was collected by a Millipore-Q system made by Bedford, MA, USA. The polypropylene membrane $(0.01 \mu \mathrm{m})$ was provided by GVS Filtration Technology, Italy. Phosphate buffer $(15 \mathrm{mM}$ ( $\mathrm{pH} 7.0))$ was arranged utilizing standard protocol. The solutions $(10.0-100.0 \mu \mathrm{g} / \mathrm{L})$ of separable and combination of phenols were arranged in 15.0 milli mole 
phosphate buffer ( $\mathrm{pH} 7.0$ ) for capillary electrophoresis experiments. The solutions of $0.25-1.5 \mathrm{mg} / \mathrm{L}$ were prepared in Millipore water for sample preparation studies.<smiles>Oc1ccccc1</smiles>

Phenol.<smiles>Nc1ccc(O)cc1</smiles>

p-Amino-phenol.

Figure 8. Chemical structures of phenol and $p$-nitro-phenol.

\subsection{Instruments Used}

The capillary electrophoresis machine was a Quanta 4000 of Waters Chromatography, Millipore, Milord, MA, USA. The software was Millennium 2000 with a data station. The analysis was performed on a fused silica capillary $(0.6 \mathrm{~m} \times 75 \mu \mathrm{m}$ I.D. $)$ and was supplied by Waters, Milord, MA, USA. The $\mathrm{pH}$ was adjusted by a $\mathrm{pH}$ meter (611, Orion Research Inc., Jacksonville, FL, USA).

\subsection{Green Synthesis of Nanomaterial}

The nanomaterial, that is, composite iron nanoparticles were manufactured utilizing green knowledge as defined elsewhere [32-35]. Black tea extract was mixed with ferrous sulphate solution and nanoparticles were prepared by green technology. Further, these nanoparticles were allowed to react with ionic liquids to make nanocomposite materials. The instinctive iron nanoparticles were obtained by mingling black tea extract and ferrous sulphate solution. The composite iron nanoparticles were manufactured utilizing $N$-methyl butyl imidazolium bromide ionic liquid.

\subsection{Fabrication of SPMMTE}

The SPMMTE unit was laboratory made as shown in Figure 9. Poly propylene membrane was molded into a cone shape [35 $\mathrm{mm} \times 35 \mathrm{~m} \times 25 \mathrm{~m}$ ]. The synthesized nanocomposite $(5.0 \mathrm{mg})$ was inserted into a cone shaped poly propylene membrane. This cone was fixed inside $200.0 \mu \mathrm{L}$ pipette micro tip. The micro tip was dipped in acetone for about $15 \mathrm{~min}$ for fixing. 


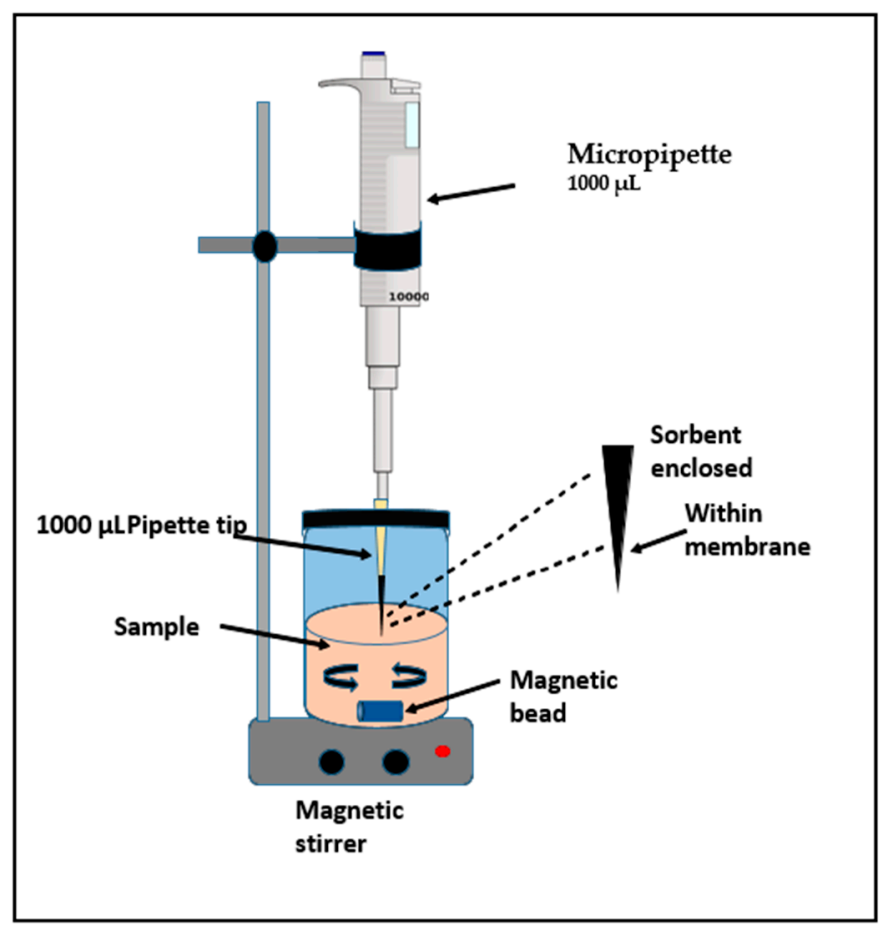

Figure 9. Solid phase micro membrane tip extraction assembly.

\subsection{Capillary Electrophoretic Conditions}

The capillary electrophoresis machine is described as above. The UV detector $(214 \mathrm{~nm})$ was on the cathode side of the machine. The background electrolyte utilized was phosphate buffer ( $\mathrm{pH} 7.0$, $15 \mathrm{mM}$ ). The experiments were made at $18 \mathrm{kV}$ used voltage. The samples were laden for $30 \mathrm{~s}$ via hydrostatic manner of injection. The data were collected at 20 points/second. The experiments were conducted at $23 \pm 1{ }^{\circ} \mathrm{C}$ temperature. The identification of the separated phenols in the sample was done by comparing the electropherograms of standard ones. The migration times of single phenols were matched with the migration times of the phenols mixture. The quantitative analyses of the phenols in water samples was ascertained using the peak areas of the standard phenols. The internal standard (nitro-phenol) was added before and quantification was achieved by using ratios of peak height or area of the component to the internal standard.

$$
\text { Conc. } \cdot \text { unknown }=[\text { AISK/AISU }] \times[\mathrm{AU} / \mathrm{AK}] \times[\text { Conc.known }],
$$

where AISK = area of peak of internal standard in known, AISU = area of peak of internal standard in unknown, $\mathrm{AU}=$ area of unknown, $\mathrm{AK}=$ area of known.

\subsection{Extraction of Phenols from Wastewater by SPMMTE}

The solution $(0.25-1.5 \mathrm{mg} / \mathrm{mL})$ of the two phenols mixtures were made in pure water. Wastewater samples were collected from the mess pipe line and filtered via Whatman filter paper No. 24 (pre-saturated with phenols). The solutions of the phenol mixture, that is, $1.0 \mathrm{~mL}$ of $0.25-1.5 \mathrm{mg} / \mathrm{L}$ concentrations were mixed to $9.0 \mathrm{~mL}$ water samples to get concentrations from 25-150 $\mu \mathrm{g} / \mathrm{L}$. The wastewater sample was shaken for about $60 \mathrm{~min}$ and kept at room temperature overnight. The extraction of phenols from wastewater samples was carried out using the SPMMTE method.

The SPMMTE tip was dipped in the wastewater sample $(10 \mathrm{~mL})$ with constant stimulation with a magnetic stirrer for $30 \mathrm{~min}$. A $200 \mu \mathrm{L}$ sample was engulfed in the SPMMTE tip at a gap of $15 \mathrm{~s}$. The engulfed wastewater was freed back into the beaker. This exercise was performed for $40 \mathrm{~min}$. The cone shaped membrane was taken away from SPMMTE and air dried. This cone shaped structure was 
shaken with methanol $(25 \mathrm{~mL})$ to extract the phenols. The methanol solution was condensed to $0.5 \mathrm{~mL}$ in a vacuum. The resultant solution was utilized for determining the concentrations of the phenols using capillary electrophoresis.

\section{Conclusions}

From the results and discussion, it is clear that the combination of solid phase micro membrane tip extraction and capillary electrophoresis is ideal for the monitoring of toxic phenol and $p$-amino-phenol in wastewater. The detection limits of phenol and $p$-amino-phenols were 0.1 and $0.2 \mu \mathrm{g} / \mathrm{L}$ after extraction and CE. The percentage recoveries are quite satisfactory for both the phenols. The method is also fast as it can be finished within $12 \mathrm{~min}$. The optimized circumstances were $100 \mathrm{~g} / \mathrm{L}$ concentration, $40 \mathrm{~min}$ contact time, $11 \mathrm{pH}, 5 \mathrm{mg} / \mathrm{mL}$ nanoparticles amounts, $60 \mathrm{~min}$ desorption time, 9 desorption $\mathrm{pH}$ and $298 \mathrm{~K}$ temperature. The maximum percent uptakes of $p$-amino-phenol and phenol were 80.0 and $85.0 \%$. The maximum percentage recoveries of $p$-amino-phenol and phenol from the nanomaterial were 99.0 and $98 \%$. Consequently, the actual extractions of $p$-amino-phenol and phenol from wastewater were 79.2 and 83.30 percent. Therefore, this combination of solid phase micro membrane tip extraction and capillary electrophoresis may be considered as suitable for the monitoring of toxic phenol and $p$-amino-phenol in any water sample.

Author Contributions: Data curation, N.H.A.-S.; Formal analysis, Z.A.A.; Methodology, L.H.A-W.; Software, H.A.; Supervision and paper writing, I.A.

Funding: This work was funded by the Deanship of Scientific Research at Princess Nourah bint Abdulrahman University, through the Research Groups Program Grant no. (RGP-1440-0017).

Conflicts of Interest: There is no conflict of interest.

\section{References}

1. Ali, I.; Gupta, V.K.; Aboul-Enein, H.Y. Hyphenation in sample preparation: Advancement from the micro to the nanoworld. J. Sep. Sci. 2008, 31, 2040-2053. [CrossRef] [PubMed]

2. Ali, I.; Kulsum, U.; ALOthman, Z.A. Advances in analyses of profens in biological and environmental samples by liquid chromatography. Curr. Pharm. Anal. 2016, 12, 158-176. [CrossRef]

3. Ali, I.; Abbasi, J.; Alothman, Z.A.; Alwarthan, A. SPMMTE and HPLC methods for the analyses of cardiovascular drugs in human plasma using new generation $C_{28}$ column. Cur. Pharm. Anal. 2016, 13, 56-62. [CrossRef]

4. Ali, I.; Rani, D.; Alothman, Z.A. Analysis of ibuprofen, pantoprazole and itopride combination therapeutic drugs in human plasma by solid phase membrane micro tip extraction (SPMMTE) and high performance liquid chromatography (HPLC) methods using new generation Core Shell $\mathrm{C}_{18}$ column. J. Liq. Chromatogr. Rel. Technol. 2016, 39, 339-345. [CrossRef]

5. The Merck Index: An Encyclopedia of Chemical, Drugs and Biological; Budavari, S.S. (Ed.) RSC Publishing: London, UK, 2013.

6. Dean-Ross, D.; Rahimi, M. Toxicity of phenolic compounds to sediment bacteria. Bull. Environ. Contam. Toxicol. 1995, 55, 245-250. [CrossRef] [PubMed]

7. Basheer, A.A. Chemical chiral pollution: Impact on the society and science and need of the regulations in the 21st century. Chirality 2018, 30, 402-406. [CrossRef] [PubMed]

8. Basheer, A.A. New generation nano-adsorbents for the removal of emerging contaminants in water. J. Mol. Liq. 2018, 261, 583-593. [CrossRef]

9. Basheer, A.A.; Ali, I. Stereoselective uptake and degradation of $( \pm)-\mathrm{o}, p$-DDD pesticide stereomers in water-sediment system. Chirality 2018, 30, 1088-1095. [CrossRef]

10. Ali, I.; Basheer, A.A.; Mbianda, X.Y.; Burakov, A.; Galunin, E.; Burakova, I.; Mkrtchyan, E.; Tkachev, A.; Grachev, V. Graphene based adsorbents for remediation of noxious pollutants from wastewater. Environ. Int. 2019, 127, 160-180. 
11. Ali, I.; Alharbi, O.M.L.; Alothman, Z.A.; Badjah, A.Y.; Abdulrahman, A. Artificial neural network modelling of amido black dye sorption on iron composite nanomaterial: Kinetics and thermodynamics studies. J. Mol. Liq. 2018, 250, 1-8. [CrossRef]

12. Ali, I.; Al-Othman, Z.A.; Alwarthan, A. Removal of secbumeton herbicide from water on composite nanoadsorbent. Desal. Water Treat. 2016, 57, 10409-10421. [CrossRef]

13. Ali, I.; Asim, M.; Khan, T.A. Arsenite removal from water by electro-coagulation on zinc-zinc and copper-copper electrodes. Int. J. Environ. Sci. Technol. 2013, 10, 377-384. [CrossRef]

14. Ali, I.; Gupta, V.K.; Aboul-Enein, H.Y. Metal ion speciation and capillary electrophoresis: Application in the new millennium. Electrophoresis 2005, 26, 3988-4002. [CrossRef] [PubMed]

15. Ali, I. Microwave assisted economic synthesis of multi walled carbon nanotubes for arsenic species removal in water: Batch and column operations. J. Mol. Liq. 2018, 271, 677-682. [CrossRef]

16. DellaGreca, M.; Monaco, P.; Pinto, G.; Pollio, A.; Previtera, L.; Temussi, F. Phytotoxicity of low-molecular-weight phenols from olive mill waste waters. Bull. Environ. Contam. Toxicol. 2001, 67, 352-359. [CrossRef]

17. Hirose, M.; Takesada, Y.; Tanaka, H.; Tamano, S.; Kato, T.; Shirai, T. Carcinogenicity of antioxidants BHA, caffeic acid, sesamol, 4-methoxyphenol and catechol at low doses, either alone or in combination and modulation of their effects in a rat medium-term multi-organ carcinogenesis model. Carcinogenesis 1998, 19, 207-212. [CrossRef] [PubMed]

18. Hooived, M.; Heederik, D.J.; Kogevinas, M.; Boffetta, P.; Needham, L.L.; Patterson, D.G., Jr.; Bueno-de-Mesquita, H.B. Second follow-up of a Dutch cohort occupationally exposed to phenoxy herbicides, chlorophenols and contaminants. Am. J. Epidemiol. 1998, 147, 891-901. [CrossRef]

19. Michałowicz, J.; Duda, W. Phenols-Sources and Toxicity. Pol. J. Environ. Stud. 2007, 16, 347-362.

20. Schweigert, N.; Zehnder, A.J.B.; Eggen, R.I.L. Chemical properties of catechols and their molecular modes of toxic action in cells, from microorganisms to mammals: Minireview. Environ. Microbiol. 2001, 3, 81-91. [CrossRef]

21. Ali, I.; Aboul-Enein, H.Y. Chiral Pollutants: Distribution, Toxicity and Analysis by Chromatography and Capillary Electrophoresis; John Wiley \& Sons: Chichester, UK, 2004.

22. Ali, I.; Aboul-Enein, H.Y.; Gupta, V.K. Nanochromatography and Capillary Electrophoresis: Pharmaceutical and Environmental Analyses; Wiley \& Sons: Hoboken, NJ, USA, 2009.

23. Ali, I.; Gupta, V.K.; Saini, V.K.; Aboul-Enein, H.Y. Analysis of phenols in wastewater using capillary electrophoresis and solid phase extraction. Int. J. Environ. Pollut. 2006, 27, 95-103. [CrossRef]

24. Ali, I.; Aboul-Enein, H.Y. Fast Screening of phenol and its derivatives in wastewater by HPLC by using monolithic silica column and solid phase extraction. Anal. Lett. 2004, 37, 235-2361. [CrossRef]

25. Ali, I.; Aboul-Enein, H.Y. Determination of phenol and its derivatives in waste water by capillary electrophoresis. Fresenius Environ. Bull. 2002, 11, 36-39.

26. Ali, I.; ALOthman, Z.A.; Sanagi, M.M. Green synthesis of iron nano-impregnated adsorbent for fast removal of fluoride from water. J. Mol. Liq. 2015, 211, 457-465. [CrossRef]

27. Ali, I.; Al-Othman, Z.A.; Alharbi, O.M.L. Uptake of pantoprazole drug residue from water using novel synthesized composite iron nanoadsorbent. J. Mol. Liq. 2016, 218, 465-472. [CrossRef]

28. Ali, I.; Kulsum, U.; ALOthman, Z.A.; Saleem, K. Analyses of nonsteroidal anti-inflammatory drugs in human plasma using dispersive nanosolid-phase extraction and high-performance liquid chromatography. Chromatographia 2016, 79, 145-157. [CrossRef]

29. Ali, I.; ALOthman, Z.A.; Alwarthan, A. Sorption, kinetics and thermodynamics studies of atrazine herbicide removal from water using iron nano-composite material. Int. J. Environ. Sci. Technol. 2016, 13, 733-742. [CrossRef]

30. United States Pharmacopeial Convention Inc. United States Pharmacopeia; United States Pharmacopeial Convention Inc.: Rockville, MD, USA, 2005.

31. IFPMA. ICH Draft Guidelines on Validation of Analytical Procedures: Definitions and Terminology; Federal Register; IFPMA: Geneva, Switzerland, 1995; Volume 60.

32. Ali, I.; ALOthman, Z.A.; Alwarthan, A. Molecular uptake of congo red dye from water on iron composite nanoparticles. J. Mol. Liq. 2016, 224, 171-176. [CrossRef] 
33. Ali, I.; Kulsum, U.; ALOthman, Z.A.; Alwarthan, A.; Saleem, K. Functionalized nanoparticles based solid-phase membrane micro-tip extraction and high-performance liquid chromatography analyses of vitamin B complex in human plasma. J. Sep. Sci. 2016, 39, 2678-2688. [CrossRef]

34. Ali, I.; ALOthman, Z.A.; Alwarthan, A. Green synthesis of functionalized iron nanoparticles and molecular liquid phase adsorption of ametryn from water. J. Mol. Liq. 2016, 221, 1168-1174. [CrossRef]

35. Ali, I.; ALOthman, Z.A.; Alwarthan, A. Synthesis of composite iron nanoadsorbent and removal of ibuprofen drug residue from water. J. Mol. Liq. 2016, 219, 858-864. [CrossRef]

Sample Availability: Samples of the compounds are available from the authors.

(C) 2019 by the authors. Licensee MDPI, Basel, Switzerland. This article is an open access article distributed under the terms and conditions of the Creative Commons Attribution (CC BY) license (http://creativecommons.org/licenses/by/4.0/). 